Revista de Ciencias Sociales - Número 65 (2014) - Páginas 147-184

La moralidad básica de la personalidad humana, en la jurisprudencia del tribunal...

\title{
LA MORALIDAD BÁSICA DE LA PERSONALIDAD HUMANA, EN LA JURISPRUDENCIA DEL TRIBUNAL EUROPEO DE DERECHOS HUMANOS: UN LÍMITE PARA LOS ASUNTOS INMIGRATORIOS
}

HUMAN PERSONALITY AS BASIC MORALITY, IN THE CASE-LAW OF THE EUROPEAN COURT OF HUMAN RIGHTS: A RESTRAINT ON IMMIGRATION MATTERS

\author{
CARLOS DORN GARRIDO* \\ Facultad de Derecho \\ Universidad de Valparaíso, Chile \\ carlosdorn@yahoo.com.ar
}

\section{Resumen}

El artículo examina la jurisprudencia de la Corte Europea de Derechos Humanos relacionada con el artículo 3 de la Convención Europea de Derechos Humanos, por la que impone límites a la potestad legal de los Estados para expulsar extranjeros o admitir su entrada al territorio. Debido a que en ciertos casos, dicho curso de acción puede ser contrario a la cláusula del convenio.

Palabras claves

Dignidad, tortura, tratos inhumanos y degradantes

\footnotetext{
* Profesor Doctor (c) Universidad Carlos III de Madrid y Magíster en Derecho de la Universidad de Valparaíso-CHILE. Artículo recibido el 15 de agosto de 2013 y aceptado el 30 de diciembre de 2013.
}

Revista de Ciencias Sociales - Número 65 (2014) - Universidad de Valparáíso - ISSN 0716-7725-Valparaíso, Chile 


\section{Abstract}

This article examines the case-law of the European Court of Human Rights, related to article 3 of the European Convention of Human Rights by which imposes limits on the legal authority of the states, either to expel foreigners or to allow their legal entrance or residence. As there are occasions where the exercise of this prerogative can be understood as a breach of covenant's provision.

\section{Keywords}

Dignity, torture, inhuman and degrading treatment.

$$
\begin{array}{r}
\text { "La patria del hombre es el mundo y si en mí consistiera, } \\
\text { borraría de todos los diccionarios la palabra extranjero" } \\
\text { (Justo Arosemena) }
\end{array}
$$

\section{Introducción}

Tras un poco más de 60 años de la aprobación de la Declaración Universal de los Derechos Humanos, por la Asamblea General de las Naciones Unidas, en 1948, todavía para una parte importante de la población mundial las palabras del preámbulo de la Declaración, son meras aspiraciones. En especial, para los ciudadanos que por razones del azar nacieron en Estados, que carecen de las condiciones mínimas para el ejercicio del derecho moral universal a la autodeterminación y emancipación propio del rasgo común de Humanidad como seres de fines. Sin embargo, este derecho moral universal de participar en el reino kantiano de los fines está coartado producto de la vigencia aún de una concepción tradicional de soberanía, que reconoce al Estado la potestad discrecional para administrar sus fronteras, y que, además, vincula la igualdad jurídica plena al estatus de ciudadano-nacional. Aspecto que segrega desfavorablemente al extranjero frente al ciudadano, pues la igualdad jurídica queda condicionada a la titularidad del estatus de nacional. En consecuencia, el extranjero queda sometido a una relación de sujeción, altamente discrecional, que habilita al Estado para decidir su admisión o expulsión de sus fronteras.

Facultad de Derecho y Ciencias Sociales - Universidad de Valparaíso - Chile 
La dicotomía ciudadano y extranjero resiente, así, el concepto de universalidad de los derechos humanos, que plantea el desafío de cómo conciliar la universalidad de su valor moral frente al particularismo de una ciudadanía etnocéntrica. La moralidad universal de los derechos humanos plantea la obligación a los Estados de armonizar el ejercicio de su potestad en materia de extranjería a las exigencias de humanidad ínsitas en el derecho moral universal de los hombres, en especial su núcleo inderogable de seres de fines, cuya vigencia debe estar ubicada más allá de las contingencias moralmente arbitrarias, como son el azar del lugar de nacimiento que toca a los hombres. En este sentido, es útil e ilustrativo la interpretación que la Corte Europea de Derechos Humanos hace sobre el artículo 3 de la Convención Europea de Derechos Humanos, para establecer límites objetivos a la potestad de extranjería. Jurisprudencia que ha sido provechosa para los casos de extranjeros que solicitan asilo o refugio. El análisis de la jurisprudencia se hará dentro de un contexto más amplio, sobre el discurso político a medio camino del compromiso real con la exigencia del valor moral de la dignidad.

\section{El derecho a salir de un país ¿y derecho a entrar a uno?}

El derecho a salir de su propio país o el de residencia es un derecho humano que representa la expresión última de la capacidad de autodeterminación individual, toda vez que una prohibición equivale a una privación de la libertad al modo de un preso carcelario, con la única diferencia de que su cárcel corresponden a las fronteras del estado.

Su calificación como derecho humano se justifica en su relación intrínseca con la dignidad humana, entendida como la capacidad racional de la persona para decidir autónomamente su plan de vida e impulsarlo. Situación que se revela en su totalidad, con motivo de las migraciones forzadas cuya causa es, precisamente, la inexistencia de las condiciones mínimas para la realización de la dignidad como expresión de autodeterminación y desarrollo individual.

Por otra parte, su reconocimiento como derecho humano, es de data reciente con la aprobación de la Declaración Universal cuyo artículo 13 numeral 2 establece que:

Revista de Ciencias Sociales - Número 65 (2014) - Universidad de Valparáíso - ISSN 0716-7725-Valparaíso, Chile 
"Toda persona tiene derecho a salir de cualquier país, incluso del propio, y a regresar a su país".

Luego, confirmado en múltiples otros instrumentos internacionales en materia de derechos humanos aprobados con posterioridad ${ }^{1}$.

No obstante lo anterior, basta un examen del derecho internacional para percatarse que existe un tratamiento y protección asimétrico entre el derecho a salir y el derecho a entrar a un país, el primero en los instrumentos internacionales está garantizado con prescindencia de la nacionalidad de la persona, no ocurre lo mismo con el segundo que solamente está asegurado para los nacionales del estado respectivo.

Ciertamente, la asimetría debilita la potencia de emancipación del derecho a salir del país, puesto que la entrada a otro depende del consentimiento del país respectivo. Si a lo anterior se le suma el resurgimiento de políticas de inmigración severamente restrictivas, el movimiento migratorio legal se dificulta entrando en escena el concepto poco afortunado de la inmigración ilegal como un riesgo que debe ser controlado y combatido desde el país de origen — como si se tratara de un acción delictiva en sí misma- y su uso indiscriminado tiene un efecto que deshumaniza a personas en cuya desesperación no tienen otra opción que abandonar su país dejando tras de sí todo.

La diferencia en el tratamiento de ambos derechos esta fundada en un reconocimiento de plena soberanía a los estados, para la administración de su territorio, lo que conlleva la inexistencia para los extranjeros de un derecho subjetivo para entrar a otro país, expresión del principio westfaliano de la soberanía interna de los Estados para administrar su territorio pudiendo excluir del ingreso y permanencia dentro de sus fronteras a los extranjeros.

1. A modo ejemplar, el art. 12.2 del Pacto de Derechos Civiles y Políticos, dice:

"Toda persona tendrá derecho a salir libremente de cualquier país, incluso del propio"; el Protocolo N ${ }^{\circ} 4$ del Convenio Europeo de Derechos Humanos, Art. 2.2, dice: "Toda persona es libre de abandonar cualquier país, incluido el suyo"; el art. 22.2 de la Convención Americana sobre Derechos Humanos, dice: "Toda persona tiene derecho a salir libremente de cualquier país, inclusive del propio"; el art. 12.2 de la Convención Africana sobre los Derechos Humanos y de los Pueblos, dice: "Toda persona tendrá derecho a salir de cualquier país, incluido el suyo (...)”.

Facultad de Derecho y Ciencias Sociales - Universidad de Valparaíso - Chile 
Sin embargo, el proceso de humanización experimentado en el Derecho internacional con el reconocimiento de la calidad de sujeto de derecho internacional de la persona humana, a consecuencia del desarrollo de un ordenamiento internacional de los derechos humanos anclado en el valor intrínseco de la dignidad humana, que impone a los Estados la observancia de un catálogo de derechos humanos con prescindencia de la nacionalidad de la persona, les impide que puedan desconocer la subjetividad de la persona humana como titular de derechos al momento de ejercer su potestad de exclusión. Las normas de derechos humanos persiguen superar el paradigma de vincula los derechos y libertades a la calidad de ciudadano de un Estado, producto de las consecuencias desastrosas derivadas de esa aproximación, especialmente en la Segunda Guerra Mundial, manifestando una preferencia por el principio de que un individuo es protegido por el Derecho en consideración a su condición de persona y no por su estatus formal de ciudadano ${ }^{2}$.

La humanización del Derecho internacional es un franco rescate de la dignidad humana, como concepto autónomo y de intrínseca igualdad de toda persona, situación que obligaría a un replanteamiento de la noción excluyente de ciudadanía por una convivencia con una ciudadanía cosmopolita o post-nacional anclada en el valor universal de la dignidad, según se verá más adelante. Lo anterior en aras de la coherencia del lenguaje de los derechos humanos, significa reconocer a cualquier persona la titularidad de derechos humanos vinculados a las exigencias morales de una igual dignidad, y revisar la compatibilidad de dichas exigencias con la relación de sujeción a la que es sometido un extranjero.

En el marco de ese contexto, estimo que la interpretación de la Corte Europea hace del artículo 3 de la convención - prohibición absoluta de tortura, tratos inhumanos o degradantes- persigue armonizar la ética de mínimos común acordada en la Convención

2. CORNELISSE, Galina: Immigration and asylum law and policy in Europe. Immigration, detention and human rights. Rethinking territorial sovereignty, Martinus Nijhoff Publishers, Netherlands, 2010. Pág. 105.

Revista de Ciencias Sociales - Número 65 (2014) - Universidad de Valparáíso - ISSN 0716-7725-Valparaíso, Chile 
Europea y otros textos internacionales, con la obligación que asumen los Estados al adherir a un instrumento de derechos humanos.

En ese orden de ideas, la Corte parece entender que la garantía contenida en la disposición citada recoge un compromiso ético-jurídico ineludible de los Estados con el núcleo moral inderogable de la humanidad, que está por sobre las consideraciones de pertenencia o no a una comunidad nacional, y del cual surge una obligación de protección mínima resumida en una prohibición de devolver a un extranjero a su país de origen, si de ello se puede desprender un riesgo real de sufrir tratos incompatibles con el artículo 3, tal como ocurre en los numerosos casos resueltos con motivo de extranjeros con órdenes de expulsión cuyas peticiones de asilo o refugio habían sido rechazadas, a cuyo respecto la opción de entrar a otro país es la única que les resta.

\section{El asilo y estatuto del refugiado: conceptos relacionados a la jurisprudencia de la Corte Europea de Derechos Humanos}

La relación planteada por la Corte entre la garantía de prohibición de tortura, tratos inhumanos o degradantes, y los efectos que las órdenes de expulsión adoptadas por los Estados contratantes pueden causar en casos concretos, la acerca en forma natural con las situaciones propias del asilo y estatuto del refugiado, contenido en la Convención de Ginebra de 1951.

En efecto, el presupuesto de hecho del asilo y refugio dice relación con personas que se encuentran en una posición de desamparo y grave compromiso de las condiciones morales de la dignidad humana, no pudiendo contar con la protección de su país de nacionalidad o de residencia. Es por ello que, su vulnerabilidad humanitaria hace que las consecuencias de una decisión de expulsión le afecten gravemente.

También sea dicho que, el asilo y refugio significan esfuerzos de la comunidad internacional por incluir obligaciones de solidaridad internacional y humanitaria que morigeren un ejercicio celoso de la soberanía territorial de los Estados respecto a personas que padecen situaciones atentatorias a la dignidad humana, aunque como diré más adelante son insuficientes porque en mayor o menor grado, la situación del extranjero depende de la voluntad discrecional del Estado careciendo de un derecho subjetivo oponible de protección.

Facultad de Derecho y Ciencias Sociales - Universidad de Valparaíso - Chile 
La jurisprudencia de la Corte según se verá adelante, en cierto modo trata de paliar las deficiencias de las figuras del asilo y refugiado, mediante una interpretación del artículo 3 de la convención orientada a reforzar la protección de los instrumentos internacionales sobre los refugiados — en sentido amplio de la palabra — más allá de sus marcos, actualizándola a las obligaciones internacionales asumidas por los Estados europeos con su adhesión a la convención. Es por ello que, resulta necesario hacer una referencia sinóptica a las figuras del asilo y refugio, para efectos de entender hacia qué derrotero se ha orientado la jurisprudencia de la Corte.

El asilo es una protección graciosa que un Estado otorga discrecionalmente, tanto en su territorio como en cualquier otro en que tenga jurisdicción, a una persona no nacional que es perseguida por otro Estado por razones políticas o ideológicas. El asilo no comporta un derecho subjetivo oponible al Estado, como quizás podría pensarse de la lectura del artículo 14 de la Declaración Universal, sino que es una manifestación de la soberanía ${ }^{3}$ correspondiendo a cada Estado calificar las circunstancias y motivos para concederlo. Lo cual presenta al asilo como una potestad estatal exclusiva y discrecional.

Si bien, en la actualidad no existe normativa internacional que imponga a los Estados la obligación de conceder asilo ${ }^{4}$, tampoco es

3. El artículo 1.1 de la Declaración sobre Asilo Territorial, adoptada por la Organización de las Naciones Unidas, el 14 de diciembre de 1967, dispone que: "El asilo concedido por un Estado, en el ejercicio de su soberanía, a las personas que tengan justificación para invocar el artículo 14 de la Declaración Universal de los Derechos Humanos, incluidas las personas que luchan contra el colonialismo, deberá ser respetado por todos los demás Estados”.

4. "Esta ausencia del derecho al asilo en los instrumentos de derecho resulta sorprendente, toda vez que la institución del asilo es bien conocida y practicada desde principio de la Historia(...) es importante notar que la protección frente a la persecución política aparece ya recogida en el Tratado de paz de Kadesh, concluido entre 1280 y 1269 a.C., entre el Faraón Ramsés II, y Hatusil III, rey de los hititas. (GIL BAZO, María Teresa: "La protección internacional del derecho del refugiado a recibir asilo en el Derecho Internacional de los Derechos Humanos”, Mariño Menéndez, Fernando (Director). En: Derecho de extranjería, asilo y refugio, Instituto de Migraciones y Servicios Sociales, Madrid, 2003, Pág. 681).

Revista de Ciencias Sociales - Número 65 (2014) - Universidad de Valparaíso - ISSN 0716-7725-Valparáís, Chile 
menos cierto que el Derecho internacional ha ido acuñando principios generales, que son una suerte de limitación a la discrecionalidad de lo estatal para el ejercicio de su facultad soberana de concesión de asilo. En ese orden de ideas, se inscribe el artículo 3.1 de la Declaración de la Asamblea General de las Naciones Unidas, sobre asilo territorial (1967), que hace aplicable el principio de no devolución — non refoulementque impide al Estado devolver a la persona cuyo asilo ha sido rechazado a cualquier Estado donde pueda ser objeto de persecución, constituyendo un límite a la prerrogativa estatal.

Ahora bien, "la debilidad de la regulación internacional del asilo - carente de un referente normativo internacional y en tanto que su concesión o denegación dependía de un acto discrecional del estadomás las insuficiencias del derecho internacional humanitario para proteger a la población civil durante un conflicto armado" ${ }^{\text {, demostró }}$ lo inadecuado del marco tradicional de protección a través de los estados individuales para dar solución a la situación de los refugiados causados en las dos conflagraciones mundiales de la primera parte del siglo $\mathrm{XX}^{6}$. Surgiendo en la comunidad internacional la necesidad de establecer un mecanismo de protección objetivo que no dependiera de la voluntad discrecional de los Estados, aspiración que se concreta en a Convención de Ginebra, sobre el estatuto de los refugiados de 1951, modificada por el Protocolo de 1967.

La figura del refugiado regulada por el Derecho internacional en la Convención de Ginebra citada ${ }^{7}$ encierra una serie de obligaciones

5. ACOSTA ESTÉVEZ, José: “La internacionalización de los derechos humanos y los mecanismos de protección de los refugiados”, Núria Camps Mirabet (ed.). En: El derecho internacional ante las migraciones forzadas. Refugiados, desplazados y otros migrantes involuntarios, Edicions de la Universitat de Lleida, Lleida, 2005, Pág. 43.

6. GIL BAZO, María Teresa, ob., cit., pág. 682.

7. La Unión Europea aprobó la Directiva 2004/83/CE, de 29 de abril de 2004, por la que se establecen normas mínimas relativas a los requisitos para el reconocimiento y el estatuto de nacionales de terceros países o apátridas como refugiados o personas que necesitan otro tipo de protección internacional y al contenido de la protección concedida. La caracterización de refugiado coincide con la Convención de Ginebra.

Facultad de Derecho y Ciencias Sociales - Universidad de Valparaíso - Chile 
para el Estado de acogida. El concepto de refugiado de la convención supone un consenso global sobre un mínimo de aquello que supone la calidad de refugiado ${ }^{8}$, integrada por la concurrencia de los siguientes cuatro elementos:

1. Que la persona se encuentra fuera de su país de origen, o siendo apátrida de su país de residencia habitual;

2. Que la persona no quiera o no pueda acogerse a la protección del Estado del que es nacional o del que tiene su residencia habitual;

3. Que lo anterior se deba a que la persona tenga fundados temores de persecución por motivos de raza, religión, nacionalidad, pertenencia a determinado grupo social u opiniones políticas y;

4. Que busque la protección en el territorio de otro Estado.

El estatuto de refugiado constituye una especie de determinado grado de asilo ${ }^{9}$ cuya regulación por el Derecho internacional causa a los Estados la asunción de determinadas obligaciones internacionales según la convención de Ginebra.

8. Otros instrumentos internacionales de alcance regional han desarrollado sus propias definiciones de refugiado. Así por ejemplo la Convención de la Organización para la Unidad Africana, sobre los problemas de los refugiados en África, en su artículo primero toma como base la definición de la Convención de Ginebra, pero la amplía para incluir a las personas que se ven obligadas a abandonar su lugar de residencia habitual debido a la agresión externa, la ocupación, la dominación extranjera o los acontecimientos que perturben gravemente el orden público en parte o la totalidad de su país de origen.

La Declaración de Cartagena sobre refugiados, de 22 de noviembre de 1984, en su conclusión tercera estima que en vista de la afluencia masiva de refugiados en el área centroamericana considera necesario extender el concepto de refugiado de la Convención de Ginebra, integrando también a las personas que han huido de sus países porque su vida, seguridad o libertad han sido amenazadas por la violencia generalizada, la agresión externa, los conflictos internos, la violación masiva de los derechos humanos u otras circunstancias que hayan perturbado gravemente el orden público.

9. KAHALE CARRILLO, Djamil Tony: El derecho de asilo frente a la violencia de género, Editorial Universitaria Ramón Areceres, Madrid, 2010, pág. 109.

Revista de Ciencias Sociales - Número 65 (2014) - Universidad de Valparáíso - ISSN 0716-7725-Valparaíso, Chile 
A mayor abundamiento, la configuración de la condición de refugiado vinculada con situaciones de grave riesgo de compromiso al núcleo de la condición moral de la humanidad, unido a la circunstancia de que las obligaciones contenidas en los tratados de derechos humanos los Estados las asumen no en relación con otro Estado sino hacia todos los individuos bajo su jurisdicción ${ }^{10}$, hacen que en teoría pueda hablarse en un sentido amplio de un derecho del refugiado a recibir asilo del Estado, limitando su potestad de expulsión. Aunque en los casos decididos por la Corte, aparece de suyo que la decisión de reconocimiento de la calidad de refugiado queda radicada en la ponderación discrecional de los antecedentes por el Estado.

De lo anteriormente expuesto, es posible colegir que la situación de los extranjeros que solicitan asilo o reconocimiento del estatuto de refugiado, es de extrema vulnerabilidad puesto que ante el Estado extranjero carecen de un derecho subjetivo que puedan oponer para que se les conceda protección, sino que por el contrario están sometidos a la voluntad discrecional de la respectiva autoridad. Es por esa razón que, la interpretación del artículo 3 contribuye a morigerar la relación de sujeción del extranjero ante el Estado, reivindicando su calidad de titular de derechos humanos básicos universales.

\section{La jurisprudencia de la Corte Europea de Derechos Humanos relacionada con el derecho de asilo a refugiados}

La relación jurídica que los Estados traban con las personas al adoptar y adherir a tratados internacionales en materia de derechos humanos, es el principio que sirve de piedra angular a la intervención de la Corte, en la revisión de las decisiones de expulsión de extranjeros adoptadas por un Estado contratante, aún cuando la convención carezca de disposiciones sobre la materia en concreto. Considera que las decisiones adoptadas por la autoridad de extranjería sobre el ingreso y/ o permanencia de un extranjero, sea rechazando peticiones de asilo o de refugio, son actos de autoridad que como tales deben adoptarse en cumplimiento de las obligaciones asumidas por el Estado con la aprobación de la convención.

10. Corte Interamericana de Derechos Humanos, Opinión Consultiva, OC-2/82, 24 de septiembre de 1982, párrafo 29.

Facultad de Derecho y Ciencias Sociales - Universidad de Valparaíso - Chile 
Así sea dicho, la principal obligación del Estado consiste en reconocer y asegurar a todas las personas dependientes de su jurisdicción los derechos humanos fundamentales, en especial para aquellos en una situación de vulnerabilidad humanitaria. Asimismo, la obligación de garantía de la cláusula de prohibición contra la tortura, tratos inhumanos o degradantes, es un imperativo que no debiera ser desatendido en la evaluación de las solicitudes de asilo o refugio, no sólo por el hondo calado moral que supone para una democracia su cumplimiento sino que, también, por el hecho que la persona que busca asilo o refugio huyó para salvar su dignidad humana, esto es, la condición moral de humanidad comprometida en la disposición del artículo 3 de la convención.

Por su parte, en el plano internacional la protección a los extranjeros desplazados de su país de origen o residencia, tiene como único texto de referencia universal a la Convención de Ginebra sobre estatuto del refugiado, la cual sigue siendo insuficiente tanto por la estrechez de su concepto como por el hecho que no existe un pronunciamiento expreso de reconocer al refugiado un derecho al asilo, y porque siempre quedará sujeto a la discrecionalidad del Estado para decidir si le reconoce la condición de refugiado pudiendo siempre rechazar su solicitud y derivarlo a un tercer país seguro que se pronuncie de su estatus de refugiado.

No obstante lo anterior, sí cabe reconocer que su principal avance lo representa su artículo 33.1 que consagra el principio de no devolución, en cuya conformidad:

"Ningún Estado contratante podrá, por expulsión o devolución, poner en modo alguno a un refugiado en las fronteras de los territorios donde su vida o libertad peligre por causa de su raza, religión, nacionalidad, pertenencia a determinado grupo social, o de sus opiniones políticas”.

La importancia del principio de no devolución es que en la actualidad es una obligación que "no juega sólo respecto a quienes hayan obtenido ya el estatuto de refugiado conforme a la Convención de 1951, sino que lo hace respecto a todo solicitante de asilo" ${ }^{11}$, siendo

11. PÉREZ BARAHONA, Sergio: "El estatuto de refugiado en la convención de ginebra de 1951". En: Revista electrónica del Departamento de Derecho de la Universidad de La Rioja, Número 1, 2003, pág. 8.

Revista de Ciencias Sociales - Número 65 (2014) - Universidad de Valparáíso - ISSN 0716-7725-Valparaíso, Chile 
un principio general del Derecho internacional que directamente limita la potestad estatal de expulsión de los extranjeros.

En el ámbito europeo la Corte a partir del principio de no devolución realiza una lectura del mismo en consonancia con la obligación contenida en el artículo 3 de la convención, en clave de extender el ámbito protectivo del principio hacia un ámbito más amplio que los márgenes estrechos de la Convención de Ginebra. Por lo demás, existe una obligación de aplicación preferente del artículo 3 en razón de la obligación general de garantía de los derechos y libertades de la convención, que los estados contratantes deben observar respecto de todas las personas que se hallen sometida a su jurisdicción dentro de su territorio, según lo dispuesto en el artículo 1 de la misma.

Si bien la Corte en su interpretación del artículo 3, no llega tan lejos como para sostener la existencia de un derecho subjetivo al asilo o refugio, sí decide aplicar la cláusula a favor de los nacionales de terceros países a cuyo respecto existe orden de devolución, expulsión o extradición hacia su Estado de origen o residencia, y enfrenten un serio riesgo de sufrir tortura, tratos inhumanos o degradantes en caso de retorno. En tales casos, considera que la medida de deportación —en sentido amplio - se transforma en un tratamiento incompatible con la disposición citada.

La decisión de la Corte de vincular las potestades de extranjería de los Estados para controlar el ingreso y permanencia de no nacionales, con el cumplimiento de la garantía de protección contra la tortura, tratos inhumanos y penas degradantes, es expuesto por primera vez en la decisión de la Comisión Europea de Derechos, en el asunto Altun c. Alemania, sobre la extradición de un ciudadano turco, señalando:

"La extradición de una persona puede, en circunstancias excepcionales, ser contraria a la Convención, particularmente respecto al artículo 3, cuando existan razones poderosas para estimar que la persona será sometida, en el Estado receptor, a tratos prohibidos conforme el artículo 3. Lo anterior se entiende sin perjuicio que el peligro no provenga de las autoridades públicas de quiénes el Estado sea responsable"12.

12. Comisión Europea de Derechos Humanos, Altun c. República Federal de Alemania, $\mathrm{N}^{\circ}$ 10.308/83, 3 de mayo de 1983.

Facultad de Derecho y Ciencias Sociales - Universidad de Valparaíso - Chile 
Sin embargo, las líneas fundamentales de la interpretación de la Corte se remontan al caso Soering c. Reino Unido ${ }^{13}$, sobre la extradición de un ciudadano alemán hacia Estados Unidos de Norteamérica para enfrentar un juicio penal a cuyo respecto la fiscalía solicitaba la pena de muerte. La Corte comienza afirmando que la convención no garantiza un derecho a no ser extraditado. Sin embargo, considera que en virtud del artículo 1 de la convención los Estados contratantes asumen un compromiso de asegurar un catálogo de derechos y libertades fundamentales a cualquier persona sometida a su jurisdicción. Lo cual entiende que se encuentra en sintonía con el carácter especial de la convención como tratado de aplicación colectiva de los derechos y libertades fundamentales y que supone interpretar la convención como un instrumento que sea una garantía efectiva y real de los valores e ideas de las sociedades democráticas. Siendo uno de estos valores fundamentales la prohibición absoluta contra la tortura, tratos inhumanos y penas degradantes.

Si bien la Corte no podía calificar la pena de muerte como un castigo contrario al artículo 3 de la convención atendida la excepción expresa del derecho a la vida prevista en su artículo 2, sí consideró que las circunstancias que acompañan una condena a muerte pueden ser contrarias al artículo 3 . Al respecto destaca la circunstancia sobre el tiempo que los condenados a muerte antes de la ejecución, deben esperar siendo más o menos prolongado en el denominado "corredor de la muerte" de la penitenciaria, estimando que ello provocaría al recurrente, dada su juventud y su estado mental, fuertes tensiones y un sufrimiento de entidad suficiente como para considerar que una decisión del gobierno británico de extraditarlo a los Estados Unidos vulneraría el artículo 3 de la convención. Dado lo anterior expresa:

"En resumen, la decisión de un estado contratante de extraditar a un fugitivo, puede suscitar problemas con el artículo 3 de la convención, y, por lo tanto, comprometer la responsabilidad del estado ante la convención, en caso que existan motivos sustanciales para que la persona, si es extraditada, enfrente riesgos reales de ser sometida a

13. Corte Europea de Derechos Humanos, Soering c. Reino Unido, No 14.038/ 88, 7 de julio de 1989.

Revista de Ciencias Sociales - Número 65 (2014) - Universidad de Valparáíso - ISSN 0716-7725-Valparaíso, Chile 
tortura, tratos inhumanos o penas degradantes en el país requirente. El establecimiento de tal responsabilidad inevitablemente implica valorar las condiciones del país solicitante en relación con los estándares del artículo 3 de la convención. Sin embargo, no existe intención de juzgar o establecer responsabilidades del estado requirente, sea ante el derecho internacional o ante a convención u otra. Por el contrario cualquier responsabilidad emanada de la convención, es aquella que involucre al estado contratante en razón de haber adoptado una acción que tiene un efecto directo en exponer a un individuo a un maltrato prohibido por la convención (párrafo 91)”.

Resulta de interés para los efectos de entender la relevancia de la doctrina fijada en Soering, que al momento de la decisión el Reino Unido aún no había adherido al protocolo sexto de la convención, cuyo artículo 1 prescribe que:

"Queda abolida la pena de muerte. Nadie podrá ser condenado a tal pena ni ejecutado".

De cuyo texto se desprende que, la obligación para el estado contratante no está limitada a que en su propio territorio una persona no sea condenada ni ejecutada a muerte sino que, además, la extensión de la obligación comprende un deber de no permitir que una persona sea ejecutada mediante su entrega a un Estado donde existan razones sustanciales para concluir que hay riesgos reales de que ello ocurra ${ }^{14}$.

El caso Soering sienta las bases de una interpretación reforzada del artículo 3, especialmente atendida su naturaleza de garantía absoluta e inderogable, en cuya conformidad el cumplimiento por los Estados contratantes de la obligación contenida en la norma, no está limitada a impedir que sus agentes públicos incurran en comportamientos incompatibles con la prohibición de la disposición sino que, también, su cumplimiento significa una prohibición de entregar a una persona a un Estado donde no existan las condiciones para garantizar la integridad física, psíquica y moral de la persona.

14. BLAKE, Nicholas y HUSAIN, Raza: "The protection of life, bodily, integrity and human dignity". En: Immigration, asylum \& human rights, Oxford University Press, United States, 2003, pág. 82.

Facultad de Derecho y Ciencias Sociales - Universidad de Valparaíso - Chile 
Con posterioridad, la doctrina Soering es aplicada en el asunto Cruz Varas c. Suecia ${ }^{15}$, un caso de expulsión de tres ciudadanos chilenos tras ser rechazadas sus solicitudes de reconocimiento del estatus de refugiado, donde cabe destacar la declaración de la Corte en cuya virtud estima que la regla aplicada en el caso Soering, constituye la manifestación de un principio general ubicado más allá de los casos de extradición:

"Aunque el presente caso involucra la expulsión y no una decisión de extradición, la Corte considera que el principio expuesto también se aplica a las decisiones de expulsión y a fortiori a casos de expulsiones en concreto (párrafo 70)".

La decisión de la Corte de extender la jurisprudencia hacia los casos de expulsión de extranjeros significa que los Estados contratantes no pueden adoptar o ejecutar expulsiones si ello implica exponer a la persona a un riesgo de sufrir tortura, tratos inhumanos o castigos degradantes en el territorio del Estado de origen o residencia habitual. Para estos efectos, la Corte aprovecha de establecer ciertos criterios para apreciar la violación del artículo 3 como consecuencia de una decisión de expulsión:

"Para determinar si existen razones sustanciales para estimar que hay un riesgo real de tratamiento contrario al artículo 3, la Corte valorará el asunto a la luz de todo el material colocado ante él o, de ser necesario, aquél obtenido de motu proprio (párrafo 75).

Más aún, atendido que la naturaleza de la responsabilidad de los estados contratantes según el artículo 3, en caso de este tipo, radica en el acto de exponer a un sujeto al riesgo de maltrato, la existencia del riesgo debe ser apreciada en conformidad con los hechos que eran de conocimiento o debían serlo por el estado contratante, al momento de la expulsión. Sin embargo, la Corte no está impedida de considerar información que aparece con posterioridad a la expulsión. Esta puede ser de valor para confirmar o refutar la apreciación realizada por el estado parte o los temores del recurrente (párrafo 76).

El maltrato debe decir relación con nivel mínimo de severidad, si se trata del ámbito de aplicación del artículo 3. La valoración de ese

15. Corte Europea de Derechos Humanos, Cruz Varas c. Suecia, No 15.576/89, 20 de marzo de 1991.

Revista de Ciencias Sociales - Número 65 (2014) - Universidad de Valparáíso - ISSN 0716-7725-Valparaíso, Chile 
umbral mínimo es, en sí mismo, relativo; depende de todas las circunstancias del caso (párrafo 83)".

Luego, en el caso Vilvarajah c. Reino Unido ${ }^{16}$ la Corte tiene oportunidad de profundizar sobre la calificación de la realidad y efectividad del riesgo de exposición al maltrato en caso de expulsión:

"El examen de la Corte sobre la existencia de un riesgo de maltrato en vulneración del artículo 3 debe ser rigurosos en vista del carácter absoluto de la disposición y al hecho que consagra uno de los valores fundamentales de las sociedades democráticas que componen el Consejo de Europa (párrafo 108). La mera posibilidad de sufrir maltrato, en tales circunstancias no es suficiente para dar lugar a una violación del artículo 3 (párrafo 111)”.

Respecto a la ponderación del riesgo de sufrir tratamientos incompatibles con el artículo 3 de la convención, la Corte también se ha pronunciado acerca de la indiferencia para estos efectos que la fuente del riesgo provenga de las autoridades del Estado de origen o de particulares. En el asunto H.L.R c. Francia, 29 de abril de 1997, sobre expulsión de un ciudadano colombiano condenado por delito de tráfico ilícito de drogas, la Corte se hace cargo del argumento del gobierno francés, en cuanto que el riesgo de tortura, tratos inhumanos o degradantes alegado por el recurrente, no provendría de las autoridades públicas colombianas sino de las represalias de los traficantes de droga colombianos, como consecuencia de la colaboración de prestada a la policía francesa, y a la incapacidad del Estado colombiano de protegerle contra los posibles ataques de estas personas. El estado francés estima que extender el ámbito de protección del artículo 3, en esa forma contradice los trabajos preparatorios de la convención, y textos de Derecho internacional que exigen en la tortura un elemento intencional de parte de las autoridades públicas del Estado receptor.

La Corte considera que:

"En razón del carácter absoluto del derecho garantizado, no excluye que el artículo 3 resulte aplicable cuando el peligro provenga de personas o grupos de personas que no ejercen una función pública.

16. Corte Europea de Derechos Humanos, Vilvarajah c. Reino Unido, $\mathrm{N}^{\text {os }} 13.163 /$ $87,13.164 / 87,13.165 / 87,13.447 / 87$ y 13.448/87, 30 de octubre de 1991 .

Facultad de Derecho y Ciencias Sociales - Universidad de Valparaíso - Chile 
A tales efectos, deberá demostrarse que ese peligro existe realmente y que las autoridades del Estado de destino no son capaces de proporcionar una protección apropiada (párrafo 40)".

Asimismo, en el caso Jabari c. Turquía ${ }^{17}$, sobre expulsión de una ciudadana iraní que solicitó asilo en Turquía debido al riesgo de ser condenada a la pena de lapidación, en Irán, por haber cometido delito de adulterio, la Corte además de reiterar la doctrina consabida sobre el principio de no devolución cuando la expulsión pueda significar exponer a la persona a tortura o tratamientos inhumanos o degradantes, consideró que la importancia del artículo 3 como marca distintiva de las sociedades democráticas, conlleva también la obligación del Estado de otorgar al extranjero un recurso efectivo contra las decisiones que buscan su expulsión y devolución a su país de origen:

"En opinión de la Corte, dado la naturaleza irreversible del daño que podría ocurrir si el riesgo de tortura o maltrato alegado se concretara y a la importancia del artículo 3, la noción de un recurso efectivo según el artículo 13 exige un escrutinio riguroso e independiente del reclamo sobre la existencia de motivos sustanciales para temer un riesgo de tratamiento contrario al artículo 3, así como la posibilidad de suspender la ejecución de la medida impugnada (párrafo 50)”.

Pero, es sin duda en el caso Chahal c. Reino Unido ${ }^{18}$, donde la Corte da un salto cualitativo en su intención de atribuir al artículo 3 una impronta de límite material fuerte frente al poder de extranjería de los Estados contratantes y, de paso reforzar la protección de los extranjeros en su condición de refugiados, en conformidad con el Convenio de Ginebra de 1951.

La controversia dice relación con la expulsión de dos ciudadanos indios y dos ciudadanos británicos. La Corte reitera su respeto al principio tradicional del Derecho internacional en cuya conformidad los Estados partes de la convención tienen el derecho a controlar la entrada, la permanencia y la salida de los no nacionales en su territorio,

17. Corte Europea de Derechos Humanos, Jabari c. Turquía, № 40.035/98, 11 de julio de 2000 .

18. Corte Europea de Derechos Humanos, Chahal c. Reino Unido, No 22.414/ 93, 15 de noviembre de 1996.

Revista de Ciencias Sociales - Número 65 (2014) - Universidad de Valparáíso - ISSN 0716-7725-Valparaíso, Chile 
así como la inexistencia de un derecho subjetivo al asilo. También, hace presente que una medida de expulsión de un extranjero decretada por un Estado parte puede constituir una vulneración del artículo 3 y, en consecuencia, comprometer la responsabilidad del Estado en caso de que existan motivos considerables para creer que el interesado corre el riesgo real de ser sometido a un trato contrario a dicho artículo, en caso de ser devuelto a su país de origen.

Sin embargo, atendido que la expulsión del ciudadano Chahal estaba motivada en razones de seguridad nacional por considerarlo el gobierno británico un peligro para al orden público, invocando para ello el artículo 32 y 33 de la Convención de Ginebra de 1951, la Corte tuvo que pronunciarse acerca de la compatibilidad de dichas cláusulas con la naturaleza absoluta e inderogable del artículo 3 de la convención, toda vez que los preceptos de la convención de Ginebra facultan a los estados la expulsión de refugiados por razones de seguridad nacional y, además, se excepciona el principio de no devolución cuando la persona sea considerada un peligro para la seguridad del país, según lo prescrito en el artículo 33 de la Convención de Ginebra de 1951.

En este orden de ideas, la Corte reitera que la garantía de prohibición de la tortura, tratos inhumanos o penas degradantes, constituye uno de los valores fundamentales de las sociedades democráticas, junto con reconocer que los Estados enfrentan en la actualidad grandes dificultades para proteger a sus comunidades de la violencia terrorista. Aunque considera que a pesar de tales circunstancias, la convención consagra en términos absolutos la prohibición de la tortura o tratos inhumanos o castigos degradantes, siendo independiente su garantía con respecto a la conducta del extranjero. Su carácter absoluto e inderogable emana del hecho de que ni la convención o los protocolos contemplan excepción alguna para dejar de aplicarla incluso en los casos más graves que puede enfrentar una Nación, tal como lo reconoce el numeral 2 del artículo 15.

Dado lo anterior considera que, el marco normativo contenido en la propia convención blinda y robustece el alcance del principio de no devolución atendida su relación intrínseca con la garantía de indemnidad e inviolabilidad física y moral de la persona recogida en el artículo 3, con lo que la protección dispensada a los extranjeros en caso

Facultad de Derecho y Ciencias Sociales - Universidad de Valparaíso - Chile 
de expulsión, es más amplia que la prevista en los artículos 32 y 33 de la Convención de Ginebra de 1951:

"La prohibición otorgada por el artículo 3 contra el maltrato es igualmente absoluta en los casos de expulsión. De manera que, cuando existan razones sustanciales para creer que un individuo enfrenta un riesgo real de ser sometido a un trato contrario al artículo 3, en caso de ser devuelto a otro estado, la responsabilidad del estado contratante respecto a su obligación de protegerlo contra esos malos tratos, queda comprometida en caso de expulsión. En tales circunstancias, las actividades del individuo en cuestión, aunque resulten indeseables y peligrosas, no pueden ser una consideración material. La protección proporcionada por el artículo 3 es, en consecuencia, más amplia que la dispensada por los artículos 32 y 33 de la Convención de las Naciones Unidas sobre el estatuto de los refugiados de 1951 (párrafo 80)"19.

La inaplicación de la excepción del principio de no devolución contemplada en el artículo 33.2 de la Convención de Ginebra de 1951, cuando existan razones sustanciales para creer que la persona será sometida a tortura, tratos inhumanos o penas degradantes, además es una interpretación que está acorde con lo dispuesto por el artículo 3 de la Convención de las Naciones Unidas, de 10 de diciembre de 1984, contra la tortura y otros tratos o penas crueles, inhumanos o degradantes:

“1. Ningún Estado Parte procederá a la expulsión, devolución o extradición de una persona a otro Estado cuando haya razones fundadas para creer que estaría en peligro de ser sometida a tortura.

2. A los efectos de determinar si existen esas razones, las autoridades competentes tendrán en cuenta todas las consideraciones pertinentes, inclusive, cuando proceda, la existencia en el Estado de que se trate de un cuadro persistente de violaciones manifiestas, patentes o masivas de los derechos humanos".

19. La doctrina sobre el carácter absoluto de la obligación contenida en el artículo 3, establecida en Chahal c. Reino Unido, es reafirmada por la Corte en el asunto Ahmed c. Austria, No 25.964/94, 17 de diciembre de 1996, referido a un ciudadano somalí a cuyo respecto el gobierno le retiró el estatuto de refugiado, tras haber cumplido una condena por delito de robo y se dispuso su expulsión hacia Somalia invocando en este caso la otra cláusula de excepción al principio de no devolución: "delito particularmente grave" prevista como en el artículo 33.2 de la Convención de Ginebra.

Revista de Ciencias Sociales - Número 65 (2014) - Universidad de Valparáíso - ISSN 0716-7725-Valparáiso, Chile 
También, la Oficina del Alto Comisionado de los Derechos Humanos, de las Naciones Unidas, en el Comentario General $N^{\circ} 20$ concerniente a la prohibición de tortura, trato cruel o inhumano contenida en el artículo 7 del Pacto de Derechos Civiles y Políticos, de 10 de marzo de $1992^{20}$, reafirma la inderogabilidad de la prohibición y del principio de no devolución:

"El texto del artículo 7 no admite limitación. El Comité, también, reafirma que, incluso en situaciones de emergencia pública tales como las señaladas en el artículo 4 del pacto, no está permitida la derogación el mandato del artículo 7 y sus disposiciones deben permanecer vigentes....En opinión del Comité, los estados partes no deben exponer a los individuos al peligro de ser sometidos a tortura, tratamientos inhumanos o penas degradantes, mediante su extradición, expulsión o devolución".

El núcleo duro de la doctrina del caso Chahal fue objeto de controversia y discusión, en el caso Saadi c. Italia ${ }^{21}$, sobre la expulsión de un ciudadano tunecino por sospechas de colaborar con células islamistas en el extranjero y suelo italiano siendo considerado un peligro para la seguridad nacional. Su petición de asilo político fue rechazada, así como los recursos contra la orden de expulsión, a pesar de proveer antecedentes acerca del riesgo real de sufrir a manos de las autoridades tunecinas represalias, persecución y tratamientos contrarios al artículo 3 de la Convención Europea, así como de la Convención de las Naciones Unidas contra la tortura ${ }^{22}$.

20. Vid.,http://www.unhchr.chr/tbs/doc.nsf/0/69 24291970754969c12563ed 004c8ae5? Opendocument

21. Corte Europea de Derechos Humanos, Saadi c. Italia, No 37.201/06, 28 de febrero de 2008.

22. El Comité contra la Tortura de Naciones Unidas, en el caso Agiza c. Suecia, de 20 de mayo 2005, se pronuncia sobre una situación similar a propósito del conocimiento de una denuncia sobre la expulsión decretada por autoridades suecas de un ciudadano egipcio a su país de origen, tras rechazar su solicitud de asilo por razones de seguridad nacional, unido al hecho que existía un requerimiento de las autoridades egipcias fundado en una condena en ausencia por delito de cooperación con una organización prohibida - terrorista-. Las autoridades suecas solicitaron en

Facultad de Derecho y Ciencias Sociales - Universidad de Valparaíso - Chile 
En el proceso ante la Corte intervino, también, el Reino Unido interesado en que se cambiara la doctrina de Chahal aduciendo que era una interpretación que entorpecía la labor de los Estados para proteger a sus ciudadanos de las amenazas del terrorismo internacional, postulando que la naturaleza absoluta de la garantía del artículo 3 solamente concernía a la obligación del Estado contratante mas no para ponderar los riesgos futuros de actos de tortura de un Estado no signatario de la convención, lo que permitiría a las autoridades en la decisiones de expulsión de extranjeros realizar un balance de intereses entre el riesgo a la seguridad nacional — peligrosidad — y el riesgo de maltrato de la persona.

La Corte rechaza el planteamiento del Reino Unido puesto que si bien es cierto que los Estados enfrentan grandes dificultades en proteger a sus sociedades de la violencia terrorista, no justifica que se pueda poner en duda la naturaleza absoluta del artículo 3. Es por ello que, estima necesario recalcar que:

forma previa a la decisión de expulsión garantías diplomáticas al Estado egipcio en orden a que el ciudadano tendría un juicio imparcial y no sería sometido a tortura, actos o castigos inhumanos o degradantes, las que le fueron otorgadas en comunicación posterior. Sin embargo, cuando fue trasladado al aeropuerto de Estocolmo la policía lo entregó a agentes egipcios y de la CIA de EE.UU. quiénes lo sometieron en presencia de la policía sueca a actos vejatorios de cacheo y de traslado en un avión extranjero. Tras su llegada a Egipto, y a pesar de las garantías diplomáticas, fue sometido a múltiples actos de tortura durante su reclusión en centros de detención hasta octubre de 2003, año en que fue dejado en libertad sin cargos por las autoridades egipcias. El Comité establece en sus párrafos 13.3 y 13.4 que las múltiples circunstancias de hecho conocidas sobre el uso generalizado de la tortura por el Estado egipcio —riesgo particularmente alto tratándose de la detención por razones políticas o de seguridad-, y corroborado por los servicios de inteligencia suecos, conducía de modo natural a la conclusión de que la expulsión se decretaba en contravención al artículo 3 de la Convención de Naciones Unidas. De lo cual se puede inferir que el Comité, también, secunda una posición de defensa de la naturaleza absoluta de la prohibición de tortura, aun cuando existan razones de seguridad nacional para decretar una expulsión (ver comunicación 233/2003, 20 de mayo 2005) . Por último, el caso posteriormente fue revisado por el Comité de Derechos Humanos de las Naciones Unidas, quien también emitió un dictamen de condena a Suecia por estimar que su actuar violó los artículos 2, 7 y 13 del Pacto de Derechos Civiles y Políticos (ver comunicación 1416/2005, 10 de noviembre de 2006).

Revista de Ciencias Sociales - Número 65 (2014) - Universidad de Valparaíso - ISSN 0716-7725-Valparaíso, Chile 
"No es posible ponderar el riesgo de maltrato en relación con los motivos considerados en la orden de expulsión, a fin de establecer si la responsabilidad del estado contratante queda comprometida según el artículo 3, a pesar que dicho maltrato sea infligido por otro estado. En ese orden de ideas, la conducta de la persona, por muy indeseable o peligrosa que sea, no puede ser considerada atendido que la protección reconocida por el artículo 3 es más amplia que la de los artículos 32 y 33 de la Convención de Ginebra de 1951 sobre el estatuto de los refugiados. Más aún esta conclusión está en línea con los puntos IV y XII de las orientaciones del Comité de Ministros del Consejo de Europa sobre los derechos humanos y la lucha contra el terrorismo (párrafo 138)".

La doctrina consolidada en la Corte respecto del alcance de la protección dispensada por el artículo 3 de la convención, es la expresión de un consenso europeo sobre una concepción de los derechos humanos anclada en la naturaleza inderogable de la inviolabilidad de la dimensión moral de la dignidad traducida en el derecho humano fundamental a existir y a no ser sometido a tortura o tratos incompatibles con la exigencia moral derivada del valor de la dignidad humana. Que sea calificada la interpretación del artículo 3 de la convención como un consenso europeo, significa fijar un contenido nuclear de comprensión de los derechos y libertades de la convención que queda fuera del margen de apreciación de los Estados contratantes, lo que en materia de extranjería implica limitar la discrecionalidad del Estado para ejercer sus poderes de expulsión, cuando de la decisión pueda derivar para el extranjero en una vulneración de su derecho a gozar de la protección de la garantía esencial a la indemnidad física y moral.

\section{La extensión del ámbito protección de la obligación contenida en el artículo 3 de la convención: más allá de la figura del refugiado de la Convención de Ginebra de 1951}

En este epígrafe quiero hacer referencia a una línea seguida por la Corte en la interpretación del ámbito de protección de la garantía del artículo 3 relacionada con la protección de las condiciones mínimas necesarias para una vida digna. El poder de extranjería de los Estados

Facultad de Derecho y Ciencias Sociales - Universidad de Valparaíso - Chile 
contratantes quedaría inhibido de ejecutarse en caso que la expulsión hacia el país de origen signifique exponer a la persona a un serio detrimento de sus condiciones de existencia a tal punto que sean susceptibles de causarle sufrimientos inhumanos o degradantes.

La intención de la Corte de interpretar el artículo 3 más allá de su sentido histórico de bastión de defensa de la indemnidad e inviolabilidad física y moral de la persona frente al poder público, en cierto modo está en línea con su doctrina de considerar a la convención como un instrumento vivo que debe ser interpretado en conformidad con los tiempos actuales, en el sentido que el objeto protegido por la disposición — la dignidad humana — no solamente puede ser violentada por actos intencionales de oficiales públicos o de particulares respecto de los cuáles el Estado carece de la capacidad de control sino que, también, lo sería por las carencias de condiciones materiales básicas en que sumen a su población.

Esta novedosa perspectiva de vulneración del artículo 3 de la convención, es considerada por la Corte en el asunto D. c. Reino Unido ${ }^{23}$, sobre la expulsión de un ciudadano de Saint Kitts condenado por posesión de drogas ilícitas que padecía un estado avanzado de SIDA, decidiendo extender su doctrina sobre limitación de la potestad de expulsión de los Estados contratantes en conformidad al carácter inderogable del artículo 3. Si bien la Corte es conciente que el principio establecido en sus precedentes, se ha venido aplicando a situaciones donde el riesgo de que la persona fuese sometida a alguno de los tratos prohibidos proviene de actos intencionales de las autoridades públicas del país de destino en casos de expulsión, o de organismos independientes del estado respecto de los cuales las autoridades no pueden ofrecer una protección adecuada, considera que dada la importancia fundamental de la garantía contenida en el artículo, señala:

"Que el Tribunal debe reservarse un margen de apreciación suficiente en relación con la aplicación del mismo a otras situaciones que puedan presentarse. No puede, por tanto, negarse al Tribunal la posibilidad de examinar la invocación del artículo 3 cuando el riesgo

23. Corte Europea de Derechos Humanos, D. c. Reino Unido, No 30.240/96, 2 de febrero de 1997.

Revista de Ciencias Sociales - Número 65 (2014) - Universidad de Valparáíso - ISSN 0716-7725-Valparaíso, Chile 
de violación proviene de factores que no comprometen, ni directa ni indirectamente, la responsabilidad de las autoridades públicas del Estado de destino o que, tomados aisladamente, no infringen por sí mismos el artículo 3. Tal restricción del campo de aplicación del artículo 3 sería contraria a la afirmación de su carácter absoluto. No obstante, en este contexto el Tribunal debe examinar rigurosamente todas las circunstancias del asunto (párrafo 40)".

A continuación, examina si existe un riesgo real que la ejecución de la expulsión del reclamante en consideración a su estado de salud, pueda significar una contravención al artículo 3. En este sentido, afirma que la cesación de las prestaciones que recibe en el Reino Unido tendría para el demandante consecuencias muy graves, que le producirían sufrimientos físicos y psicológicos extremos, en atención a lo avanzado de la enfermedad. También, considera que aún cuando recibiera tratamiento en su país, sería ineficaz debido a la falta de acceso a vivienda y una dieta apropiada, quedando expuesto a los problemas de salud e higiene que sufren la población en general, sin perjuicio de sopesar que carece de parientes cercanos que le brinden soporte material y moral. Conforme a lo anterior, la Corte expresó que:

"En vista de estas condiciones excepcionales y manteniendo en mente el estado crítico que ha alcanzado la mortal enfermedad del peticionario, la implementación de la decisión de enviarlo a San Kitts constituiría un tratamiento inhumano (...) (párrafo 53)”.

Junto con lo anterior, hace hincapié que el Estado demandado ha venido asumiendo la responsabilidad del tratamiento del demandante desde agosto de 1994, siendo dependiente de los cuidados médicos que recibe y está psicológicamente preparado para afrontar la muerte en un entorno que ya les es familiar y humano.

No obstante que, la decisión representa una interpretación novedosa de la garantía en razón de su sintonía con las consecuencias derivadas de tomarse en serio la universalidad de los derechos humanos, la Corte decide limitar los efectos de su decisión desechando de antemano que las condiciones económicas y sociales precarias de un Estado sean por sí mismas una vulneración al artículo 3, sino que en el particular dichas condiciones son violatorias a la disposición porque exponen a un riesgo real de muerte al recurrente, en consideración a su estado de salud.

Facultad de Derecho y Ciencias Sociales - Universidad de Valparaíso - Chile 
Su autolimitación solamente se explica ante la evidencia de que su interpretación podía servir a la inclusión en la cláusula como tratamiento contrarios a ella, a todos aquellos casos de personas que huyen de sus lugares de origen buscando una vida digna, ya que sus Estados son incapaces de garantizar condiciones básicas para la vida, tales como: vivienda, trabajo, educación, salud ${ }^{24}$. Siendo un reflejo claro de que el discurso de la universalidad de los derechos humanos sigue lastrada por el peso aún relevante que ejerce el concepto excluyente de ciudadanía como estatus de acceso al goce de ciertos derechos, entre ellos a las condiciones básicas citadas.

De otro modo, parece inexplicable desde la perspectiva de lo que significa la dignidad humana sostener que las condiciones de precariedad económica y social que aguardaban al reclamante a su regreso por sí mismas no son violatorias al estándar del artículo 3, y preocuparse de enfatizar que:

"Los extranjeros que han cumplido su condena penal y cuya expulsión se ordena, no pueden en principio reclamar derecho alguno a permanecer en el territorio de un estado contratante, a fin de poder continuar disfrutando de beneficios médicos, sociales u otras formas de asistencia proporcionada por el estado durante su permanencia en prisión. Sin embargo, atendida las circunstancias excepcionales de este caso y dado las ineludibles consideraciones humanitarias en juego, conduce a concluir que la decisión de expulsar al reclamante constituiría una violación del artículo 3 (párrafo 54)".

24. La excepcionalidad del criterio establecido en el asunto D. c. Reino Unido, es refinado y reiterado por la Comisión Europea de Derechos Humanos, en el asunto B.B c. Francia, No 30.930/96, 28 de septiembre de 1998, sobre la expulsión ordenada por el estado francés de un ciudadano congolés que sufría estado avanzado de SIDA y que, por su condición de salud, requería de atención médica constante que su país no le puede proporcionar.

También, véase asunto SCC c. Suecia, No 46.553/99, 15 de febrero de 2000, en aquella oportunidad la Comisión declaró inadmisible un reclamo contra la expulsión de una ciudadana de Zambia que comenzó a recibir tratamiento retroviral en Suecia, pues se consideró que el estado de avance de la enfermedad unido a que en su país existe el mismo tratamiento médico que en Suecia, y a que allí se encuentra su hijo y familiares, no satisfacen el estándar establecido en D. c. Reino Unido, con lo cual su expulsión no representa una violación del artículo 3.

Revista de Ciencias Sociales - Número 65 (2014) - Universidad de Valparáíso - ISSN 0716-7725-Valparáiso, Chile 
La conclusión anterior conduce a preguntarse seriamente hasta dónde los Estados se toman en serio el valor de la dignidad humana, como expresión de los derechos humanos y de las exigencias morales mínimas — no por eso menos exigente- comunes a toda persona de la especie humana. Resulta intolerable aún que la condición de ciudadano o extranjero sean categorías definitorias en las posibilidades reales de realización de un proyecto vital acorde con el valor intrínseco y autónomo de la dignidad.

\section{La jurisprudencia de la Corte sobre el artículo 3: ¿cambia en algo la tensión entre universalidad de los derechos del hombre y el concepto de ciudadanía moderno?}

La trascendencia de la labor realizada por la Corte Europea de aplicar el artículo 3 de la convención como un límite directo a la potestad de expulsión de los extranjeros de los Estados contratantes, radica en que es una posición que hace frente a las exigencias éticas derivadas de la construcción del ideal universalista de los derechos humanos, al concepto moderno de ciudadanía de sesgo exclusivamente etnocéntrico como presupuesto de acceso al goce de derechos políticos, civiles y sociales.

En este sentido, no puede caber duda que el esfuerzo desplegado es un aporte relevante ya que se hace cargo de la categoría diferencial que separa a los hombres entre nacionales y extranjeros, junto con desnudar la incompatibilidad que existe entre el estatus jurídico de extranjero y el valor universal de la dignidad humana como fundamento de los derechos humanos.

La dicotomía entre nacionales y extranjeros que justifica el reconocimiento al Estado de un poder para excluir a todos aquellos que no son nacionales se remonta, por una parte, al principio de Derecho internacional westfaliano de la soberanía externa, en cuya virtud se reconoce a los Estados pleno poder para gobernar en forma exclusiva sobre su territorio y la población que habita en él y, por otra, al concepto moderno de ciudadanía vinculado a la identidad nacional.

Sin duda que, a la noción moderna de ciudadanía le corresponde un papel importante en la distinción entre nacionales y extranjeros,

Facultad de Derecho y Ciencias Sociales - Universidad de Valparaíso - Chile 
especialmente, en lo que concierne al estatus jurídico de derechos que se desprenden de uno u otro, al punto que la condición de acceso a los denominados derechos fundamentales exige la calidad de ciudadano, sin que baste la sola pertenencia a la comunidad humana.

La explicación de la dualidad hombre/ciudadano encontraría su origen en la interdependencia entre soberanía y derechos que inspira a la Declaración de los Derechos del Hombre y el Ciudadano, como consecuencia del hecho que el ideario político de la revolución francesa debe desarrollarse en un contexto dado de un Estado moderno con un territorio, fronteras definidas, y con un aparato burocrático ordenado de modo vertical culminando la cadena con la figura del monarca. Asimismo, la doctrina de la soberanía popular que transforma al gobierno en impersonal, introduciendo la idea de la igualdad como reemplazo a los lazos personales que servían de fundamento al poder político propio de la monarquía, condujo obligadamente a que la revolución deba dotar de un contenido concreto a la idea de igualdad que inspira su ideario, para lo que debió afrontar dos procesos. Primero, los privilegios y el orden feudal es abolido siendo reemplazado por la noción de ciudadano anclado en el principio de la igual política del individuo, cuyo desarrollo es progresivo. Segundo, la revolución ocurre en un contexto de un Estado formado por un aparato estatal burocrático central y jerarquizado, estructura que debía ser integrada en la abstracción de un cuerpo político basado en la soberanía popular. Lo que hace necesario recurrir a una nueva idea que imprima mayor concreción a la representación de la idea abstracta de un cuerpo político gobernado por el pueblo, así como una nueva identidad política que otorgue expresión a la igualdad política. Aparece, así, en escena la idea de Nación como entidad política que es la fuente de la igualdad y de ciudadanía en una versión que aúna dos ideas distintas de libertad, la expresión clásica de una política y otra legal que vincula a la ciudadanía la existencia igual para todos los ciudadanos de un estatus de derechos individuales ${ }^{25}$.

La concepción dual hombre/ciudadano genera un conflicto entre el ideal universalista de los derechos humanos y la especificación de

25. CORNELISSE, Galina, ob., cit., págs. 53, 73 -74.

Revista de Ciencias Sociales - Número 65 (2014) - Universidad de Valparáíso - ISSN 0716-7725-Valparaíso, Chile 
ciudadanía — miembro de una comunidad política — que si bien fue un medio efectivo para la implementación de los Derechos del Hombre, no es menos cierto que es una idea que impuso límite al ideal universal de los mismos. Junto con ello, dicha dualidad en el proceso de formación de los Estados dejó la puerta abierta para reclamos de tinte nacionalista -étnicos- que demandan una concreción más real y cercana que la sola noción de pueblo y Nación ${ }^{26}$.

Las consecuencias desastrosas para la Humanidad de la identificación de los Derechos del Hombre con los derechos de los ciudadanos se hace patente en el siglo XX, con la ola de refugiados, apátridas y víctimas de los gobiernos totalitarios, demostrando que los Derechos del Hombre, supuestamente inalienables eran ineficaces para aquellos personas que ya no eran ciudadanos de Estado alguno. Las palabras de Hanna Arendt son reveladoras al afirmar que:

"Nadie había sido consciente de que la Humanidad, considerada por tanto tiempo bajo la imagen de una familia de naciones, había alcanzado una fase en la que todo el que era arrojado de una de estas comunidades cerradas y estrechamente organizadas se hallaba al mismo tiempo arrojado de la familia de naciones... Incluso los nazis comenzaron su exterminio de los judíos privándoles de todo status legal (el status de ciudadanía de segunda clase)...Sólo en una Humanidad completamente organizada podía llegar a identificarse la pérdida del hogar y del status político con la expulsión de la Humanidad..."27.

Las consecuencias humanitarias derivadas de la identificación de los denominados Derechos del Hombre con el estatus jurídico de ciudadano o, lo que es lo mismo, de pertenencia a una determinada comunidad política, derivó en un rescate de la idea de universalidad de los derechos humanos, correspondiendo a los Estados la obligación de respetarlos con prescindencia de la nacionalidad o condición de ciudadano de la persona.

26. Ibídem., Pág. 80.

27. ARENDT, Hanna: "La decadencia de la nación-estado y el final de los derechos del hombre”. En: Los orígenes del totalitarismo, V.2, Alianza Universal, Madrid, 1987, págs. 426, 429 y 430.

Facultad de Derecho y Ciencias Sociales - Universidad de Valparaíso - Chile 
La aprobación por la Asamblea General de las Naciones Unidas de la Declaración Universal de los Derechos Humanos, es una clara expresión de esto último al reivindicar la dignidad de la persona como un valor intrínseco de todo ser humano, con prescindencia de cualquier condición, circunstancia o preferencia externa, reconociendo en ella la fuente de la universalidad de los derechos humanos.

La Declaración Universal representa un hito que dio lugar a un prolífico desarrollo de un Derecho internacional de los derechos humanos ${ }^{28}$, lo que repercutió, en la comprensión tradicional del Derecho

28. Se puede citar a modo ejemplar: la Convención Europea de Derechos Humanos, de 4 de septiembre de 1950, que si bien no menciona expresamente en su preámbulo o articulado la dignidad de la persona se entiende incluida por la remisión expresa que hace su preámbulo a la Declaración Universal de los Derechos Humanos de las Naciones Unidas; la Convención suplementaria sobre la abolición de la esclavitud, de 7 de septiembre de 1956; la Declaración de los Derechos del Niño, de 20 de noviembre de 1959; la Declaración sobre la concesión de la independencia a los países y pueblos coloniales, de 14 de diciembre de 1960; la Declaración de las Naciones Unidas sobre la eliminación de todas las formas de discriminación racial, de 20 de noviembre de 1963; la Declaración de los Principios de la cooperación cultural internacional, adoptada por la Conferencia General de la UNESCO de 4 de noviembre de 1966; Pacto de derechos civiles y políticos, así como el pacto de derechos económicos, sociales y culturales, ambos del 16 de diciembre de 1966; Convención Americana sobre Derechos Humanos, 22 de noviembre de 1969; la Declaración de derechos del retrasado mental, de 20 de diciembre de 1971; la Declaración sobre la protección de todas las personas contra la tortura y otros tratos o penas crueles, inhumanos o degradantes, 9 de diciembre de 1975; la Convención contra la eliminación contra toda forma de discriminación contra la mujer, de 18 de diciembre de 1979; la Declaración sobre la eliminación de todas las formas de intolerancia y discriminación fundadas en la religión o las convicciones, de 25 de noviembre de 1981; la Convención contra la tortura, y otros tratos crueles, inhumanos o degradantes, de 10 de diciembre de 1984; la Convención sobre los Derechos del Niño, de 20 de noviembre de 1989; la Declaración sobre los derechos de las personas pertenecientes a minorías nacionales o étnicas, religiosas y lingüísticas, de 18 de diciembre de 1992; la Declaración sobre la protección de todas las personas contra las desapariciones forzadas, de 18 de diciembre de 1992; Estatuto de Roma de la Corte Penal Internacional, aprobado el 17 de julio de 1998, por la Conferencia Diplomática de Plenipotenciarios de las Naciones Unidas sobre el establecimiento de una corte penal internacional; Declaración de las Naciones Unidas sobre los derechos de los pueblos indígenas, de 13 de septiembre de 2007; Convención Internacional de Naciones Unidas para la protección de todas las personas contra las desapariciones forzadas, de 20 de diciembre de 2006; y Declaración de las Naciones

Revista de Ciencias Sociales - Número 65 (2014) - Universidad de Valparaíso - ISSN 0716-7725-Valparáís, Chile 
internacional como instrumento de regulación para la relación entre los estados, al reivindicar la calidad de sujeto de Derecho internacional a la persona humana, redefiniendo la relación entre los Estados y las personas. De este modo, el Derecho internacional a partir de 1945 experimenta un proceso de humanización caracterizado por integrar a los derechos humanos como aquellas exigencias más elementales de la convivencia de la sociedad internacional ${ }^{29}$.

La influencia ejercida por las normas internacionales de los derechos humanos, da inicio a un proceso de continua difuminación de la separación rígida y férrea, entre ámbito interno y externo de los Estados — herencia de la Paz de Westfalia - y su principal expresión en el principio de no injerencia de los Estados en los asuntos internos de otro.

La identificación de los derechos humanos con la condición de humanidad, impide a los Estados invocar como asunto interno lo que se refiere al tratamiento de su población, pasando a ser una cuestión de derecho internacional. Al mismo tiempo, el estatus de ciudadano nacional, tampoco, puede ser considerado como el fundamento exclusivo de los derechos, en atención que el Derecho internacional garantiza derechos fundamentales con absoluta prescindencia de su nacionalidad ${ }^{30}$, en especial merecen atención los derechos humanos fundamentales expresados en los artículos 1 a 5 de la Declaración Universal de los Derechos Humanos de las Naciones Unidas, que expresan el núcleo ético universal de la dignidad humana, al igual que el Título I de la Carta Europea de Derechos Humanos ${ }^{31}$.

Unidas sobre el sexagésimo aniversario de la Declaración Universal de los Derechos Humanos, 10 de diciembre de 2008.

29. ACOSTA ESTÉVEZ, José, ob., cit., pág. 22.

30. CORNELISSE, Galina, ob., cit., pág. 101.

31. El título I de la Carta de los Derechos Fundamentales Europea, denominado simplemente Dignidad, en su artículo 1 proclama el carácter inviolable de la

dignidad humana y el correspondiente deber de protección y respeto, y el resto de los artículos del título son un reconocimiento, también, de las manifestaciones mínimas e inherentes al principio del respeto de la dignidad humana: derecho a la vida (artículo 2), a la integridad de la persona (artículo 3), la prohibición de tortura y de las penas o los tratos inhumanos y degradantes (artículo 4), y prohibición de la esclavitud y trabajado forzado (artículo 5).

Facultad de Derecho y Ciencias Sociales - Universidad de Valparaíso - Chile 
Sería una confirmación del consenso universal en torno a un plexo axiológico condensado en derechos humanos esenciales que reivindican los valores de la dignidad, la libertad e igualdad, cuya construcción requiere un acuerdo amplio sobre unos cimientos éticos transculturales como son los derechos inherentes e inalienables de la persona humana, traducción concreta de la manifestación mínima e irreductible del significado del valor intrínseco de la persona. La inexistencia de estos presupuestos mínimos de la dignidad humana hace que sea insostenible articular un discurso lógico y coherente sobre los derechos humanos.

Sin embargo, y a pesar del desarrollo de las normas internacionales sobre Derechos Humanos, aún existe una brecha importante entre los derechos del hombre y los del ciudadano que coartan la fuerza emancipadora del valor intrínseco de la dignidad humana que inspira al concepto de los derechos humanos. La condición de extranjero continúa siendo una traba importante a la expresión primordial de la dignidad humana, entendida como libertad de autodeterminación orientada a la realización del desarrollo individual, toda vez que el hecho fortuito del nacimiento en un determinado país condiciona el ejercicio real de la libertad de emancipación personal. Sin duda que, representa un contrasentido al ideal común de los derechos humanos puesto que "si la lucha por los derechos humanos es la lucha contra la exclusión, es decir, la lucha por su reconocimiento más allá y por encima de las fronteras, una mirada al mundo que nos rodea parece acreditar más bien que todavía hoy, las fronteras parecen más poderosas que los derechos" 32 .

En el marco de este contexto, la jurisprudencia de la Corte es un avance en la reivindicación del respeto de las condiciones morales esenciales de la humanidad, y de la calidad de sujeto de derecho del extranjero. Quedando impedidos los Estados contratantes de ordenar expulsiones que supongan una consecuencia incompatible con la garantía del artículo 3, lo que significa en los hechos reforzar la protección del principio de no devolución comprendiendo un campo más extenso que el de la Convención de Ginebra de 1951. Empero, queda a medio camino de ser una defensa plena de la dignidad humana

32. DE LUCAS, Javier: El desafío de las fronteras. Derechos humanos y xenofobia frente a una sociedad plural, Temas de Hoy, Madrid, 1994, págs. 24-25.

Revista de Ciencias Sociales - Número 65 (2014) - Universidad de Valparáíso - ISSN 0716-7725-Valparáiso, Chile 
del extranjero ya que solamente se limita a impedir la expulsión hacia el país de origen, pero no inhibe a que el Estado pueda expulsar al extranjero hacia un tercer país seguro, pudiendo darse la situación que un extranjero pase años itinerando entre distintos países que niegan su asilo, lo que sin duda es un trato inhumano y degradante.

También, hay que reconocer que la defensa limitada a la dignidad humana contenida en el artículo 3 de la convención, en parte es resultado del carácter subsidiario de su jurisdicción, limitación que no hace más que revelar la falta de compromiso real de los Estados con la universalidad de los derechos humanos. En efecto, el reconocimiento de la dignidad de la persona como fundamento de los derechos humanos significa una defensa del valor igual de toda persona, cuya concreción exigiría algo más que el mero fortalecimiento del principio de no devolución para los extranjeros humanitariamente vulnerables sino que, debiera desembocar en el reconocimiento de un derecho subjetivo oponible a los Estados para obtener asilo o refugio, ya que los derechos humanos son un estatuto personal de ciudadanía cosmopolita.

Si los Estados quieren tomarse en serio la universalidad de los derechos humanos, entonces deben invertir los términos relativos actuales que se manifiestan en someter al extranjero a una relación de sujeción donde sus derechos quedan condicionados a la voluntad discrecional del Estado. Lo anterior pasa por reconocer que, junto a la ciudadanía nacional existe una cosmopolita derivada de la universalidad de los derechos humanos, que conlleva la consecuencia de reconocer la calidad de sujeto de derecho del extranjero, esto es, derechos subjetivos oponibles como sería el de obtener asilo o refugio cuando su país de origen o residencia no sea capaz de otorgar o asegurar las condiciones mínimas para el ejercicio de los derechos humanos identificados con el núcleo de la dignidad humana.

En este orden de ideas, resulta de interés tomar en consideración el planteamiento que atribuye a la Declaración Universal de 1948, entre otras cosas, a la creación de una ciudadanía cosmopolita derivada del carácter universal de las exigencias morales de los derechos humanos, la cual no anula la ciudadanía tradicional que vincula a una persona con un Estado, sino que ambas son compatibles y complementarias ${ }^{33}$.

33. FERNÁNDEZ GARCÍA, Eusebio: "La universalidad de los derechos humanos. Desde un ideal común, hacia una ciudadanía cosmopolita”. En: Valores constitucionales y derecho, Dykinson, Madrid, 2009, pág. 124.

Facultad de Derecho y Ciencias Sociales - Universidad de Valparaíso - Chile 
La defensa por una ciudadanía cosmopolita implica introducir un elemento de coherencia al discurso de los derechos humanos basado en la defensa de un igual valor de la persona humana, que exige superar el modelo de exclusión de la ciudadanía tradicional que repercute en la negación de una garantía jurídica plena en el ejercicio de derechos y libertades necesarios para una vida digna, tal como lo sufren los emigrantes, inmigrantes, apátridas o los refugiados. Sin embargo, la ciudadanía cosmopolita no implica desvincular a la persona de su pertenencia con una comunidad nacional concreta, más bien readecuar el concepto de ciudadanía tradicional hacia una mirada republicana vinculada con derechos y deberes cívicos propios de su relación con dicha comunidad.

En síntesis, "si queremos tomarnos en serio los derechos humanos fundamentales, debemos desvincularlos de la condición de ciudadaníanacional y conectarlos con la condición de ciudadanía-cosmopolita, pero hemos de valorar también la existencia de otro tipo de derechos y deberes derivados de la pertenencia a comunidades nacionales" ${ }^{34}$. Ciertamente que, un esfuerzo hacia esta dirección permitiría cerrar progresivamente la tensión entre el discurso universalista de los derechos humanos y las particularidades excluyentes de la ciudadanía etnocéntrica.

\section{Conclusión}

La interpretación de la Corte Europea se decanta por una defensa fuerte de las condiciones inderogables e inviolables de la personalidad humana, contenida en el citado artículo 3. Siendo eso, así, el Tribunal ha conseguido restringir el ámbito de aplicación de la excepción que al principio de no devolución dispone el artículo 33.2 de la Convención de Ginebra citada. Con ello, se establece la primacía de la garantía de los derechos humanos básicos sobre consideraciones de Razón de Estado, como lo la invocación del peligro para el orden público o la seguridad nacional.

34. FERNÁNDEZ GARCÍA, Eusebio: "Derechos humanos y ética globalizada". En: Dignidad humana y ciudadanía cosmopolita, Dykinson, Madrid, 2001, pág. 110.

Revista de Ciencias Sociales - Número 65 (2014) - Universidad de Valparáíso - ISSN 0716-7725-Valparaíso, Chile 
También, la interpretación es más amplia que, incluso, la sostenida por el Comité de las Naciones Unidas contra la Tortura, en su Observación General N ${ }^{\circ}$ 1, del artículo 3 de la respectiva Convención de Naciones Unidas, adoptada en su sesión 317 del decimonoveno periodo de sesiones, 21 de noviembre de 1997. El Comité limita la protección de la disposición solamente a los casos de riesgo probable de sufrir el individuo actos de tortura, en el marco de la definición del artículo 1 de la misma Convención. Quedando, la protección de la garantía con un tono más limitado, en dos aspectos:

1. La interpretación del Comité excluye del ámbito de protección de la norma del artículo 3 de la Convención de Naciones Unidas, aquellos actos que sin ser tortura sean inhumanos o degradantes. Apartándose de la línea seguida por la Corte Europea que incluye, también, a las deficitarias condiciones económicas y sociales de un país como circunstancias potencialmente constitutivas de actos contrarios a las condiciones morales de la dignidad y;

2. El Comité restringe el sentido de la expresión del párrafo 2 del artículo $3^{35}$, en cuanto que los actos allí enunciados solamente pueden entenderse referidos a las violaciones cometidas por un funcionario público u otra persona en el ejercicio de funciones públicas, a instigación suya o con su consentimiento o aquiescencia. Tal lectura contrasta con la interpretación de la Corte Europea en el caso H.L.R. contra Francia ya comentado, en virtud del cual se extiende la protección a los actos provenientes de grupos privados fuera del ámbito de control del Estado.

Sin perjuicio de lo anterior, la labor de la Corte Europea para someter el ejercicio del poder de extranjería de los Estados contratantes al respeto del núcleo moral inderogable de la personalidad humana, es insuficiente. Porque, la protección dispensada por la aplicación reforzada del principio de no devolución, no consigue brindar protección

35. Art. 3.2: "A los efectos de determinar si existen esas razones, las autoridades competentes tendrán en cuenta todas las consideraciones pertinentes, inclusive, cuando proceda, la existencia en el Estado de que se trate de un cuadro persistente de violaciones manifiestas, patentes o masivas de los derechos humanos".

Facultad de Derecho y Ciencias Sociales - Universidad de Valparaíso - Chile 
frente al estado de desamparo del extranjero que busca asilo o refugio en otro país. En efecto, la prohibición de expulsión, ni conlleva la obligación para el Estado contratante de conceder asilo o de reconocer el estatus de refugiado, por tanto siempre puede derivarlo a un tercer país seguro para que sea aquél quien resuelva sobre su solicitud de asilo o refugio.

La interpretación de la Corte Europea desnuda la contradicción entre la teoría y praxis de la universalidad de los derechos humanos básicos. ¿Es posible sostener la universalidad de los mismos y, simultáneamente, mantener una concepción de ciudadanía anclada exclusivamente en la identidad nacional como presupuesto de acceso al disfrute de derechos y libertades indispensables para una vida digna?

Ciertamente, es una ironía la profusas declaraciones sobre la importancia angular de la dignidad humana, cuando en los hechos el azar del lugar de nacimiento significa para muchos ser tratados como personas sin derechos. Pues, le son negados no solamente en su país de nacimiento, al ser incapaz de proporcionarle las condiciones materiales básicas para una vida digna, sino que además son rechazados en terceros países, ya que en su condición de extranjero carece del derecho a entrar o permanecer en otro país, en búsqueda de las condiciones que le son negadas.

Por lo tanto, parece más que razonable postular la existencia en todo ser humano de una doble ciudadanía, aquella que lo liga con una determinada comunidad nacional pero, también, otra que mantiene su vínculo con la humanidad, esto es, una ciudadanía cosmopolita entendida como una calidad nacida del igual valor de todo ser humano, lo que justifica reconocer la titularidad de los derechos y libertades esenciales para la concreción del ideal emancipador de la dignidad humana. La ciudadanía cosmopolita de la igual dignidad de los derechos humanos debe desplazar las fronteras de la exclusión, y no que sean las fronteras particulares de los Estados las que excluyan la concreción de la igual dignidad de los derechos humanos ${ }^{36}$.

36. En este último punto muy instructivos son los comentarios de John Rawls, en su obra El derecho de gentes, con respecto a la vinculación de la noción de decencia con el estándar mínimo para formar parte de la Sociedad de los Pueblos. Siendo, los derechos humanos básicos el criterio principal de la idea de justicia denominada decencia (Vid., RAWLS, John, El derecho de gentes y "Una revisión de la idea de razón pública", Paidós, Barcelona, 2001, [Trad. Hernando Valencia Villa]).

Revista de Ciencias Sociales - Número 65 (2014) - Universidad de Valparáíso - ISSN 0716-7725-Valparaíso, Chile 


\section{BIBLIOGRAFÍA}

\section{Libros y artículos}

ACOSTA ESTÉVEZ, José, "La internacionalización de los derechos humanos y los mecanismos de protección de los refugiados". En:

Núria Camps Mirabet (ed.), El derecho internacional ante las migraciones forzadas. Refugiados, desplazados y otros migrantes involuntarios, Edicions de la Universitat de Lleida, Lleida, 2005.

ARENDT, Hanna, "La decadencia de la nación-estado y el final de los derechos del hombre”. En: Los orígenes del totalitarismo, V.2, Alianza Universal, Madrid, 1987.

BLAKE, Nicholas y HUSAIN, Raza, "The protection of life, bodily, integrity and human dignity". En: Immigration, asylum \& human rights, Oxford University Press, United States, 2003.

CORNELISSE, Galina, Immigration and asylum law and policy in Europe. Immigration, detention and human rights. Rethinking territorial sovereignty, Martinus Nijhoff Publishers, Netherlands, 2010. DE LUCAS, Javier, El desafío de las fronteras. Derechos humanos y xenofobia frente a una sociedad plural, Temas de Hoy, Madrid, 1994.

FERNÁNDEZ GARCÍA, Eusebio:

"Derechos humanos y ética globalizada". En: Dignidad humana y ciudadanía cosmopolita, Dykinson, Madrid, 2001.

__ "La universalidad de los derechos humanos. Desde un ideal común, hacia una ciudadanía cosmopolita”. En: Valores constitucionales y derecho, Dykinson, Madrid, 2009.

GIL BAZO, María Teresa, "La protección internacional del derecho del refugiado a recibir asilo en el Derecho Internacional de los

Derechos Humanos”. En: Mariño Menéndez, Fernando (Director), Derecho de extranjería, asilo y refugio, Instituto de Migraciones y Servicios Sociales, Madrid, 2003.

KAHALE CARRILLO, Djamil Tony, El derecho de asilo frente a la violencia de género, Editorial Universitaria Ramón Areceres, Madrid, 2010.

PÉREZ BARAHONA, Sergio, "El estatuto de refugiado en la convención de ginebra de 1951”. En: Revista electrónica del

Facultad de Derecho y Ciencias Sociales - Universidad de Valparaíso - Chile 
La moralidad básica de la personalidad humana, en la jurisprudencia del tribunal...

Departamento de Derecho de la Universidad de La Rioja, Número 1, 2003, p.8. Texto disponible en sitio: dialnet.unirioja.es/servlet// revista? codigo $^{2} 2206$

RAWLS, John, El derecho de gentes y "una revisión de la idea de razón pública”, Paidós, Barcelona, 2001, Trad. Hernando Valencia Villa.

\section{Legislación internacional}

Organización de las Naciones Unidas:

— Pacto de Derechos Civiles y Políticos, 16 de diciembre 1966.

- Declaración sobre Asilo Territorial, 14 de diciembre 1967.

- Comité contra la Tortura, Observación General No 1 , sobre alcance del artículo 3 de la Convención de Naciones Unidas contra la Tortura, adoptada en su sesión 317 del decimonoveno período de sesiones, 21 de noviembre 1997.

_- Oficina del Alto Comisionado, Comentario General No20 concerniente a la prohibición de tortura, trato cruel o inhumano contenida en el artículo 7 del Pacto de Derechos Civiles y Políticos, de 10 de marzo de 1992.

Carta Europea de los Derechos Fundamentales, 18 de diciembre 2000. Consejo de Europa, Convenio Europeo de Derechos Humanos, 4 de noviembre 1950.

Consejo de la Unión Europea, Directiva 2004/83/CE, de 29 de abril 2004.

Organización de los Estados Americanos, Convención Americana sobre Derechos Humanos, 22 de noviembre de 1969.

Organización para la Unidad Africana:

- Convención Africana sobre los Derechos Humanos y de los Pueblos, 27 de julio 1981.

_- Convención sobre los problemas de los refugiados en África, 10 de diciembre 1969.

Declaración de Cartagena sobre refugiados, de 22 de noviembre 1984.

\section{Jurisprudencia}

Comité de Naciones Unidas contra la Tortura, Agiza c. Suecia, comunicación $\mathrm{N}^{\circ}$ 233/2003, 20 de mayo 2005.

Revista de Ciencias Sociales - Número 65 (2014) - Universidad de Valparáíso - ISSN 0716-7725-Valparáíso, Chile 
Comisión Europea de Derechos Humanos:

___ Altun c. República Federal de Alemania, No 10.308/83, 3 de mayo 1983.

_- B.B c. Francia, No 30.930/96, 28 de septiembre 1998.

SCC c. Suecia, No 46.553/99, 15 de febrero 2000.

Corte Europea de Derechos Humanos:

—_ Soering c. Reino Unido, No 14.038/88, 7 de julio 1989.

Cruz Varas c. Suecia, No 15.576/89, 20 de marzo 1991.

__ Vilvarajah c. Reino Unido, Nos 13.163/87, 13.164/87, 13.165/87, 13.447/87 y 13.448/87, 30 de octubre 1991 .

Chahal c. Reino Unido, No 22.414/93, 15 de noviembre 1996.

—_ Ahmed c. Austria, No 25.964/94, 17 de diciembre 1996.

—_ D. c. Reino Unido, No 30.240/96, 2 de febrero 1997.

—_ Jabari c. Turquía, No 40.035/98, 11 de julio 2000.

__ Saadi c. Italia, No 37.201/06, 28 de febrero 2008.

Corte Interamericana de Derechos Humanos, Opinión Consultiva, OC-2/82, 24 de septiembre 1982. 